Review Article

\title{
Evolution of poverty alleviation programme in India
}

\author{
Archana Thakur ${ }^{1}$, Richa Gautam ${ }^{1 *}$, Ekta Gupta ${ }^{2}$
}

\begin{abstract}
${ }^{1}$ Department of Community Medicine, Hamdard Institute of Medical Sciences and Research, New Delhi, India
${ }^{2}$ ICMR- National Institute of Cancer Prevention and Research (NICPR), Noida, Uttar Pradesh, India
\end{abstract}

Received: 30 June 2021

Accepted: 07 July 2021

*Correspondence:

Dr. Richa Gautam,

E-mail: richa.gautam1@gmail.com

Copyright: () the author(s), publisher and licensee Medip Academy. This is an open-access article distributed under the terms of the Creative Commons Attribution Non-Commercial License, which permits unrestricted non-commercial use, distribution, and reproduction in any medium, provided the original work is properly cited.

\begin{abstract}
Since independence, India has made huge economic progress which no doubt has raised the standard of living of our people but still the journey to eradicate poverty is quite long. One third of Indian population is living below the minimum income which is required for subsistence. Poverty is a major social determinant of health as poor people lack access to basic social amenities like safe water, sanitation, food security, health infrastructure etc., which makes them highly vulnerable to deadly diseases. On the other hand, catastrophic expenditure on health and loss of economic productivity due to disease makes millions of people poor every year. Seeing the grave situation, Government of India has launched various poverty alleviation programmes from time to time. In this review we discuss evolution of employment generation programme since its inception in India. We also focus on upcoming challenges in further reducing the poverty rate and future opportunities.
\end{abstract}

Keywords: Evolution, India, Poverty, Poverty alleviation

\section{INTRODUCTION}

After independence, India was suffering from underdeveloped economy. There was some development in British rule, but it was not uniform across country, mainly confined to urban pockets. Agriculture was the mainstay of life in rural population where $83 \%$ of population lived, but productivity was very low in agriculture sector. Moreover, population was continuously increasing but there was less growth of alternative occupation to absorb growing population. This caused chronic unemployment and low income among rural population. Till date, $80 \%$ of the India's poor population live in rural areas. So, our poverty alleviation programmes in India first launched in the year 1952 in rural areas and named as Community Development and since then many programmes were launched in rural India. But in later years, urban poverty was also gaining attention as rural poor migrating to urban and settling in the unauthorized colonies or urban slums and so, in the year 1985, first urban poverty alleviation programme was launched. ${ }^{1}$
Based on 3 main determinants of poverty i.e lack of income and purchasing power, increasing price of food and inadequacy of social infrastructure, poverty alleviation programmes can be broadly divided into 3 categories which are employment programmes, housing programme and others that include National Health Mission, Food Security Mission and National Social Assistance Programme. ${ }^{2}$ The present paper will mainly discuss evolution of these employment programmes in rural and urban India (Figure 4).

Employment programme are of two types- wage employment and self-employment programme.

\section{WAGE EMPLOYMENT PROGRAMME IN RURAL} INDIA

Rural Manpower programme was first wage employment programme which was launched in year 1960-1961. The objective was to provide 100 days employment to 2.5 
million people by end of 3rd FYP. Due to resource constraint it came to an end by 1968-1969 as only $20 \%$ of total originally envisaged outlay of Rs. 150 crores could be provided. The programme generated 137 million man-days of employment against the target of 250 million mandays. $^{3,4}$

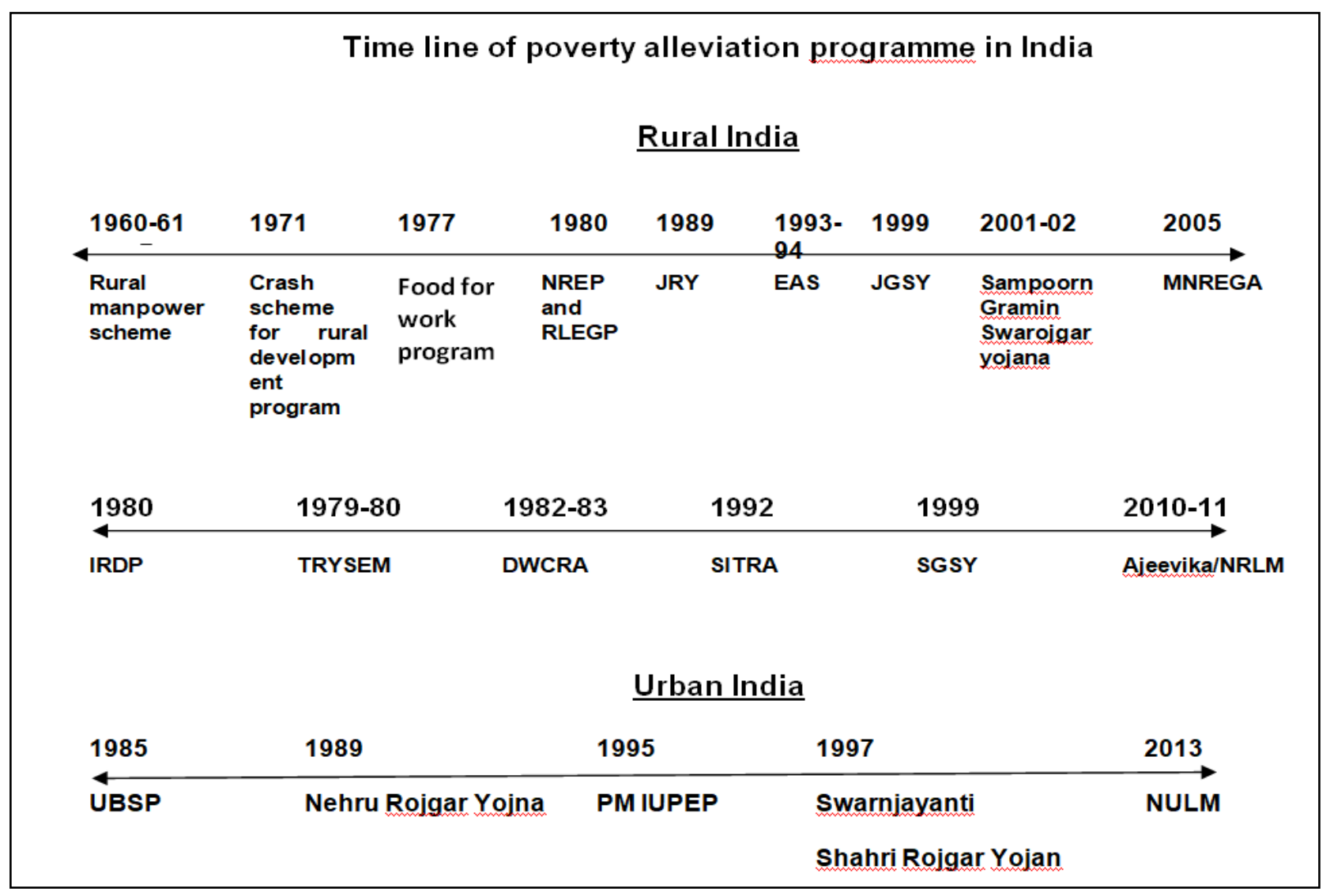

Figure 4: Employment programme.

Then, Crash scheme for rural development programme came in year 1971 for 3 years to provide employment to 1000 persons per annum in each district through the execution of labor-intensive projects and creation of durable assets like roads, means of irrigation, soil conservation, culverts, afforestation, land reclamation, development of Panchayat land etc. The total outlay sanctioned for the scheme was Rs.142.74 crore in 3 years, of which Rs. 122.63 crore was released and the State governments and Union Territories spent Rs. 2.75 crore, bringing the total expenditure to Rs. 125.38 crore. It was alleged that almost all the States and Union Territories either underpaid the laborer's or spent less amount on materials used in the construction of projects than the ratio prescribed by the Central Government. It had badly affected the interest of the laborers and quality of assets generated. Moreover, inadequate publicity for the scheme, chance of better wages elsewhere, contractual obligations and preoccupation with own holdings were also reasons for the non-popularity of the scheme.,

In year 1977, Food for work programme was launched with additional feature of providing food grains along with wage to increase nutritional status of labor and meet. The programme became very popular in rural communities and included all ongoing plan and non-plan works in the community. the programme generated 979.32 million man-days during the period $1977-78$ to $1979-80$. On evaluation of programme, it was found that this was providing benefit to small and non-target section of society. It was mainly due to difference in employment requirement of two groups i.e. longer period of employment required for landless and seasonal employment require in case of agriculture workers. Also, due to lack of planning, state governments failed to develop useful projects and various assets of dubious utility were developed. Later financial constraints and lack of administrative and technical backup, many works taken up were non-durable in nature and were often executed through contractors. So, finally the programme was revamped and renamed as National Rural employment programme (NREP) in the year $1980 .^{3}$

NREP aimed to "generate additional gainful employment for the unemployed and underemployed persons in rural areas with the target of 300-400-million-man days per year, and to create productive community assets for direct and continuing benefits to poverty groups and to strengthen the rural, economic and social infrastructure to bring about a general improvement in the overall quality of 
life in rural areas. The wages were paid in the form of cash and food grains (maximum upto $2 \mathrm{~kg}$ grains per head per day). The total outlay envisaged for the programme was Rs. 2473.11 crore during the 6th Plan and total Rs. 1842.78 crore was actually spent with generation of 1774.37 million man-days in the 6th FYP. Later the programme was merged into the Jawahar Rozgar Yojana. ${ }^{3}$

Rural Landless Employment Guarantee Programme (RLEGP) was launched in the year 1983 and had objective of providing 100 days employment to at least one member of each landless rural household and creating durable assets for strengthening the rural infrastructure. 3 Later the programme was merged in Jawahar Rojgar Yojna (JRY).

JRY merged NREP and RLEGP in 1989, and targeted the population below poverty line. Under this programme, priority was given to SC/ST and freed bonded labor. Only unskilled labor work was provided instead of mechanized work to increase employment. Also, to increase inclusion, $30 \%$ of employment to women was set. Employment was provided in lean agriculture season mainly. Creation of assets was based on felt needs at village through Panchayat Raj Institutions (PRIs). 2,3,6,7

After three years of its implementation, i.e. in 1992-1993, a review of the programme revealed that per person employment generated was inadequate in terms of the requirement and did not provide enough income to the poor. It was also perceived that the resources under JRY were too thinly spread and adequate attention was not being given to the backward areas of the country. Accordingly, the strategy for implementation of JRY was modified from 1993-1994, with the introduction of second stream of JRY added, and 120 backward districts in 12 states characterized by high concentration of poor and underemployed, were selected and provision of 90-100 days employment per person were made in these districts. The programme was implemented through Panchayat Raj Institutions (PRIs). But it was found that training was not given to PRIs. Though employment to SC/ST was more than $50 \%$, only $16.59 \%$ of women were employed and $49 \%$ of work couldn't be completed on time. The second stream of JRY merged with Employment Assurance programme (EAS) in year 1993-1994. The EAS programme was introduced in 1775 backward blocks. Funds were provided according to incidence of poverty and 100 days of unskilled work during lean agriculture work on minimum wages was provided. ${ }^{2,8}$

In JRY and EAS, wage employment was getting priority over assets creation and assets were created haphazardly without proper planning. Though poverty rate decreased from $50 \%$ to $37 \%$ in $1993-1994$ but absolute number of poor was still high. To overcome the limitations of JRY, Jawahar Gram Samridhi Yojana (JGSY) came in year 1999, to focus on development of village infrastructure in planned manner and assets base on felt needs were given priority under this programme. ${ }^{16,17}$ Later in year 20012002, JGSY and EAS were merged in Sampoorn Gramin
Swarojgar Yojna. The primary objective of the scheme was to provide additional and supplementary wage employment and thereby provide food security and improve nutritional levels in all rural area and secondary objective was the creation of durable community, social and economic assets and infrastructural development in rural areas. Inefficient monitoring and evaluation and maintenance of data were major problem in the programme. Another objective was to provide food security, but there was no evidence about impact of allocated supply of food grains., ${ }^{9,10}$

Current wage employment programme in rural India is Mahatma Gandhi National Rural Employment Guarantee Act 2005 (MGNREGA). The vision of this act is to provide livelihood security by making mandatory provision of minimum 100 days of guaranteed wage employment each year to adult members volunteer to do unskilled manual work. This was first time when provision of employment was made right based. Also, the programme focused on rural development by creating durable assets. On an average, each year 5 crore household has been given employment from 2008 to 2018 at an average 45-46 mandays against the target of 100 days. But the programme managed to be socially inclusive as each year $55.6 \%$ of beneficiaries were women and $41 \%$ where beneficiaries were SC/ST. ${ }^{11-13}$

\section{SELF-EMPLOYMENT PROGRAMME IN RURAL INDIA}

In the year 1980, Integrated Rural Development Programme (IDRP) was launched. The programme aimed at providing assistance to the beneficiaries in the form of Bank credit and Government subsidy so as to help them sustainable income generating assets. The target group of the programme consisted of families Below the Poverty Line (BPL) in rural areas comprising those landless and small and marginal farmers, agricultural labourers, rural artisans etc. With the objective of further strengthening the IRDP, there were few allied/sub-Programmes as well. These were Development of Women and Children in Rural Areas (DWCRA) (started in 1982-1983), Training of Rural Youth in Self Employment (TRYSEM) started in 19791980) and Supply of Improved Tool kits to Rural Artisans (SITRA) (started in July, 1992). This programme was successful in providing incremental income to poor families but in most of the cases, income was not adequate to enable beneficiaries to cross poverty line. The main constraint was poor investment in the programme. ${ }^{2,3,7,14}$

Later in year 1999, this programme was replaced by Swarnjayanti Gram Swarojgar Yojna (SGSY). The beneficiaries were rural BPL families. The main components of the programme were: formation of self-help groups (SHG)- SHGs were group of poor people who volunteered to organize themselves for eradication of poverty of group members, apacity building of SHG, income generating assets through credit cum subsidy plan, partnership with banks and NGO. 
After 10 years of programme, only, 25 million households were organized into SHG and only $22 \%$ of that could get subsidy. The main drawback of the programme was: poor access to credit from banks due to fear of recovering of loans, only one time loan rather than multistage credit, ineffective efforts for skill training, poor access to market for products by swarojgaries, uneven geographic spread of SHG, high attrition rate among self-help group, focus on single livelihood but poor people have to survive on more than one livelihood to earn sufficient, states were not able to absorb funds given under SGSY and no SHG federations. Need of SHG federations were felt for production enhancement, marketing linkages and bank credits. $^{21}$ So, in 2010-2011, National rural livelihood Mission or "Ajeeivika" launched and replaced SGSY. The target is to cover 70 million poor rural household in $>600$ districts 6000 blocks, 6 lacs villages in 10 years. To reach actual beneficiaries, the poor will be identified by Panchayat Raj Institutions, based on participatory identification of the poor not on basis of BPL criteria. Also, SHG federations at village level and block level will be established to give strength to SHGs activities. NRLM aims to benefit the SHG members by social inclusion i.e. access to public services, (enrollment of their children in school, access to health care services etc.), access to entitlement (MGNREGA, Public distribution System etc), food security, gender empowerment, improved health and Nutrition by Community run Nutrition centers, financial Inclusion by access to credits and increasing savings, and economic inclusion by capacity building of the SHG members for self-employment and building new job skills so according to changing market. ${ }^{15}$

\section{POVERTY ALLEVIATION PROGRAMMES IN URBAN INDIA}

In 7th Five Year plan, need for urban poverty alleviation programme was felt and Nehru Rojgar Yojna was launched in 1989 with 3 sub-schemes, Scheme for Urban Micro enterprises (SUME), Scheme for Urban Wage Employment programme (SUWE) and Scheme of housing and shelter up gradation programme (SHASU). Urban Basic scheme for the poor (UBSP) was launched in year 1985 with the specific objectives of effective achievement of the social sector goals: community organization, mobilization and empowerment; and convergence through sustainable support system. ${ }^{2,16}$ Another programme Prime Minister's Integrated Urban Poverty Eradication Programme (PM IUPEP) came in 1995 to provide basic services, improvement of sanitation and housing, employment generation and shelter up gradation and for environment improvement. Five million urban poor were targeted to benefit under the programme in 5 years. ${ }^{2,17}$ Later, in the year 1997, both the Programme Nehru Rojgar Yojna and PM IUPEP replaced with Swarnjayanti Shahri Rojgar Yojna with the same objective. In this programme, Community development societies were used for identification of beneficiaries. Its 2 sub components are Urban Self-Employment Programme (USEP) and Urban Wage Employment Programme (UWEP). In USEP, assistance to beneficiaries was provided for selfemployment and skill development training to beneficiaries was provided. ${ }^{9,17}$ But again the major problems remained difficulty in identification of poor, limited focus on mobilization of poor into SHGs, lack of capacity building, lack of flow of credit for selfemployment and lack of integrated approach for skill development. ${ }^{18}$ So, in 2013, National Urban livelihood mission (NULM) was launched to address these issues. ${ }^{19}$

National Urban Livelihood mission aims to reduce poverty and vulnerability of poor by providing them access to gainful self-employment and skilled wage employment opportunities through self-help groups. It also aims to provide shelter to homeless with basic services in phase manner. It also addresses livelihood concern of street venders by facilitating access to suitable access, institution credit, social security and skills to urban street venders for accessing emerging market linkages. Components of the programme are: social mobilization and institution development, capacity building and training, employment through skill training and placement, self-employment programme, support to urban street venders and scheme of shelter for urban homeless. ${ }^{19}$

\section{CHALLENGES AND OPPORTUNITIES}

Millennium summit in 2000 identified world's main development challenges including poverty reduction and 8 goals were developed. MDG have been the most successful anti-poverty push in history globally as well as for India. Though India has already achieved the poverty rate $21.9 \%$ (as per Tendulkar poverty line) against the target of $23.9 \% .^{20,21}$

The reduction in poverty and India's Growing Economy is not accompanied by decreasing inequality rather it has been raising since 1991 . Rising inequality combined with horizontal inequality across caste, religion, region and gender threatens to hurt the India growth story along with the social and political stability. Eighty two percent of the wealth generated in the year 2018, went to the richest one percent of the global population, while the 3.7 billion people who make up the poorest half of the world saw no increase in their wealth. ${ }^{22}$

If we take a deep insight in these poverty alleviation programmes, all the poverty alleviation programmes are entitled for BPL families which are identified according to poverty line, based on minimum need or expenditure required for subsistence of a life. This does not include savings, recreational activities, health and education and neglecting these cannot raise the standard of living of the poor. Our country has always struggled to define who is poor. Despite of so many committees formed over the last many decades, there has never been a correct insight into who are the legitimate beneficiaries of the welfare schemes. Further, the official estimates of the poor have always tended to underestimate the number of poor in comparison to the estimates done by international 
organizations such as World Bank. So, to overcome these, our government has conducted a Socio-economic caste census to identify real beneficiaries and prevent any duplication of entitlement. SECC use various deprivation parameters and automatic inclusion criteria which makes it more useful tool to identify beneficiaries of social welfare system. ${ }^{23}$

Another concern is geographic challenges of India. Major part of Indian population is living in highly remote areas, difficult terrains and conflict affected areas. Poverty is less responsive to growth in such economies because the availability of jobs is irregular and limited. Conflicts, whether they arise because of contested natural resource wealth or are politically motivated, inevitably disrupt or even reverse growth. The impact of conflict is often felt long after peace is restored. All the poverty alleviation programmes are based on employment generation and assets creation, but none of them incorporated natural resources into economic decision making. As considerable number of people in India living in rural area mainly dependent on forest for their livelihood and some depend on life under water as major source of food. So, we need to maintain our natural resources too besides keeping pace with economic development.

Another concern is, despite the enormous growth of private sectors and key role played by these private sectors in overall development of the country, responsibility of providing solutions for global poverty has traditionally fallen to governments and international aid agencies and private sectors has been singled out. From creating jobs and enhancing education to producing the goods and services used by those in poverty. Private sectors can play their role in poverty reduction in many ways. Government has to play an important role in integrating private sectors in anti- poverty programmes. ${ }^{24}$

To overcome these shortcomings Sustainable Development Goals which aims to end poverty in all its forms everywhere is focusing on to build a green economy to achieve sustainable development and lift people out of poverty. It demands reach of economic growth to each and every corner of world and use of multidimensional poverty assessment by the countries taking into account the nonincome dimensions of poverty like education, health and living standards. ${ }^{25}$

\section{CONCLUSION}

To conclude, Poverty alleviation programs in India have been a step in the right direction but they have set out to achieve a mammoth task owing to the massive BPL population involved. By concentrating on just economic up-liftment or generation of jobs for the poor without focusing on proper implementation of schemes and ignoring the other important determinants, we continue to fail to eradicate poverty in all its forms, ultimately failing to provide our people a happy and wholesome life.
Funding: No funding sources Conflict of interest: None declared Ethical approval: Not required

\section{REFERENCES}

1. Government of India, Planning commission. First Five year plan, 1951-56. Government of India, Yojna Bhavan, Delhi. 1951. Available at: http://planning commission.nic.in/plans/planrel/index.php?state= planbody.htm. Accessed on 8th July, 2016.

2. Government of India, Planning commission. Ninth Five year plan, 1997-2002, Volume 2. Government of India. 1997. Available at: http://planningcommission.nic.in/plans/planrel/index.php?state= planbody.htm.Accessed on 8th July, 2016.

3. Government of India, Planning commission. Report of working group on Poverty Allieviation programme for 10th Five-year plan. Government of India, Ministry of Rural Development, Krishi Bhawan, New Delhi. 2001.

4. Government of India, Planning commission of India (1967). Report on evaluation of rural manpower projects. Available at: http://planningcommission .gov.in/reports/peoreport/cmpdmpeo/volume1/rerm. pdf. Accessed on 9th July, 2016.

5. Government of India, planning commission of India 1979. Study of crash scheme for rural employment (1971-74). PEO Study No.104. Available at: http://planningcommission.nic.in/reports/peoreport/ cmpdmpeo/volume2/soc.pdf. Accessed on 9th July, 2016.

6. Government of India, Planning commission of India. Jawahar Rozgar Yojana: a quick study. PEO Study No. 147. Available at: http://planningcommission.nic .in/reports/peoreport/cmpdmpeo/volume1/147.pdf Accessed on 15th August, 2016.

7. Government of India, Planning commission of India. Development and poverty alleviation. Eight five year plan. Available at: http://planningcommission. gov.in/plans/planrel/fiveyr/8th/vol2/8v2ch2.htm. Accessed on 15th August, 2016.

8. Government of India, Planning commission of India. Study Reports: Executive Summary, Jawahar Gram Samridhi Yojana (JGSY). http://planningcom mission.nic.in/reports/sereport/ser/separd/sdexsum1. htm. Accessed on 20th August, 2016.

9. Poverty Alleviation and Employment Generation Programmes. Available at: http://indiabudget. nic.in/es99-2000/chap1004.pdf. Accessed on 15th September, 2016.

10. Government of India, Ministry of Rural development. Guidelines: Sampoorna Grameen Rozgar Yojana (S G R Y). Krishi Bhawan New Delhi. Available at: http://www.tn.gov.in/dtp/gorders/SGRY_Guidelines .pdf accessed on 20th September, 2016.

11. Government of India, Ministry of Rural Development, Mahatma Gandhi National Rural Employment Gauantee Act, 2005 (MGNREGA). Operational guidelines 2013,4th edition. GOI. 
Available at: http://planningcommission.nic.in/about us/committee/index.php?about=wrkg16_61.htm Accessed on 6th October, 2016.

12. Ministry of Rural Development, Government of India. MGNREGA Sameeksha 2012.GOI. http://nrega.nic.in/Circular_Archive/archive/MGNR EGA_SAMEEKSHA.pdf. Accessed on 6th October, 2016.

13. Ministry of Rural Development Government of India, Mahatma Gandhi National Rural Employment Guarantee Act 2005. Available at: https://nrega. nic.in/netnrega/mgnrega_new/Nrega_home.aspx. Accessed on 28th July, 2021.

14. Government of India, Planning Commission Evaluation Report on SGSY J\&K. 2009. Programme Evaluation Organization. Planning Commission. GOI. Available at: http://planningcommission. nic.in/reports/peoreport/peo/peosgsy.pdf. Accessed on 10th October, 2016.

15. Ministry of Rural Development Government of India. National rural livelihood Mission. 2010-11. GOI. http://aajeevika.gov.in/content/genesis. Accessed on 14th October, 2016.

16. Dutta I. Poverty to Empowerment. 2011. https://books.google.co.in/books?isbn=8184247095. Accessed on 17th November, 2016.

17. Chandra R. Social development in India. 2004 https://books.google.co.in/books?isbn=8182050278. Accessed on 18th November, 2016.

18. Government of India. Ministry of urban affairs and Employment. Swarnjayanti Shahri Rojgar Yojna Guidelines. Available at: http://smb.gov.in/ schemes/Swarna_Jayanti_Shahari_Rozgar_Yojana.p df. Accessed on 13th December, 2016.

19. Government of India, Ministry of Housing and Urban poverty alleviation. National urban livelihood Mission.2013. https://nulm.gov.in/PDF/NULM Mission/NULM_mission_document.pdf. Accessed on 18th December, 2016.
20. United nation development programme, India. Millennium Development Goals. Available at: www.in.undp.org/content/india/en/home/post2015/mdgoverview.html. Accessed on 20th February, 2017.

21. Government of India, Planning commission. Report of expert group to review the methodology for measurement of poverty. 2014. Planning commision. GOI. http://planningcommission.nic.in/reports/genr ep/pov_rep0707.pdf. Accessed on 18th December, 2017.

22. Oxfam international, Richest 1 percent bagged 82percent of wealth created last year- poorest half of humanity got nothing. Available at: https://www. oxfam.org/en/pressroom/pressreleases/2018-0122/richest-1-percent-bagged-82-percent-wealthcreated-last-year/. Accessed on: 28th July, 2021.

23. Registrar general of India. Census of India: Socioeconomic and caste. Available at: http://censusindia.gov.in/2011-Circulars/Socio _Economic_Circular1.html/. Accessed on: 28th July, 2021.

24. The Borgen project, The role of private sector in poverty alleviation. Available at: https://borgenproject.org/priv ate-sector-in-povertyalleviation/. Accessed on 28th July, 2021.

25. United nation development programme. Sustainable Development Goals. www.undp.org/content/un dp/en/home/sustainable-development-goals.html. Accessed on 28th July, 2021.

Cite this article as: Thakur A, Gautam R, Gupta E. Evolution of poverty alleviation programme in India. Int J Community Med Public Health 2021;8:4616-21. 